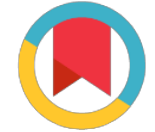

Check for updates
*For correspondence:

badrul@amdi.usm.edu.my

Competing interests: The authors declare that no competing interests exist.

Received: 2017-04-29

Accepted: 2017-05-30

Published: 2017-09-05

Copyright The Author(s) 2017. This article is published with open access by BioMedPress (BMP).

This article is distributed under the terms of the Creative Commons Attribution License (CC-BY 4.0) which permits any use, distribution, and reproduction in any medium, provided the original author(s) and the source are credited.

\section{Aerosol-based cell delivery as an innovative treatment for lung diseases}

\author{
Badrul Hisham Yahaya, Nur Shuhaidatul Sarmiza Abdul Halim, Egi Kardia \\ Regenerative Medicine Cluster, Advanced Medical and Dental Institute, Universiti Sains \\ Malaysia, Bertam, 13200 Kepala Batas, Pulau Pinang
}

\section{Abstract}

Endogenous repair mechanism of airway epithelial cells often fails to achieve sufficient cellular turnover and diminish with age, thus leading to permanent alterations in the structure and function of the airway epithelium. The therapeutic use of stem cells and progenitor cells represents a promising alternative for clinical strategy in treating acute and chronic lung disorders. Aerosol-based cell therapy is a novel therapeutic strategy in enhancing reparative process following both acute and chronic lung injuries. In such background, this study was aimed to determine the effect of aerosol-based cell delivery using MicroSprayer ${ }^{\circledR}$ Aerosolizer in the setting of acute lung injury (ALI) and ovalbumin-induced airway injury in the rabbit. In vitro evaluation revealed that the aerosol technique didn't cause a significant effect on cell morphology, viability and proliferation capability over the course of cell culture period. Aerosol delivery of airway epithelial cells (AEC) and mesenchymal stem cell (MSC) resulted in uniform distribution in the distal airway and lung interstitial region. Short term assessment showed that cells delivered to the lungs via aerosol was found to be safe for transplantation with no signs of cell rejection and histopathological alterations in the liver and spleen of all treated animals. Histological evidences also demonstrated that administration of AEC and MSC via aerosolization into the respiratory airway prevented lung inflammation as well as resulted in improvement of both alveolar damage and permeability. To our knowledge, this is the first report of aerosol cell delivery via a Microsprayer ${ }^{\circledR}$ Aerosolizer device to the lungs of rabbits to treat airway injuries. Our findings provide a promising evidence that aerosol-based cell therapy may provide a basis for the development of an innovative approach for the treatment lung injuries.

\section{Keywords}

aerosol, mesenchymal stem cell, airway epithelial cells, lung injuries

\section{Funding}

\section{References}

